\title{
CHARACTERISTICS OF FLUVISOLS IN SAND AND GRAVEL DEPOSIT "KRIVA BARA", SOFIA, BULGARIA
}

\author{
Vladimir Ilinkin, Dimitar Dimitrov, Peter Zhelev
}

\begin{abstract}
The paper presents results of an investigation on Fluvisols located in "Kriva Bara" Sofia, Bulgaria. Soil samples were taken from sixteen soil profiles. The soil physical and chemical properties were studied. The changes in physical and chemical properties at varying soil depths were studied and the relationships among different soil characteristics were tested by correlation analysis. The results revealed that some soil characteristics, such as soil texture, porosity and TKN, changed strongly with soil depth, either negatively or positively, while such relationships were moderately expressed or statistically insignificant in the case of other soil characteristics, such as soil reaction $(\mathrm{pH}), \mathrm{CaCO}_{3}$, silt content. There were significant correlations between the physical and chemical soil properties in 49 out of 78 cases.
\end{abstract}

Key words: Fluvisols, physical properties, chemical properties, gravel and sand deposit, quarry

\section{INTRODUCTION}

The sustainable development and productivity of suburban green areas depend to a great extent on the soil properties. Soil characteristics determine the existence and normal functioning of ecosystems. The studies on the soil composition and properties allow suitable planned activities to ensure efficient and environmentally use.

Fluvisols are intrazonal and occur in the riverside environment [1]. They are characterized by variable physicochemical properties $[2 ; 3]$, but have a favourable water regime $[4 ; 1]$ and good bulk density indicators [5]. They are characterized by acid, neutral or alkaline reaction in relation to river basins. Soil organic matter (SOM) is average or low, but varies strongly [3] and may reach up to $2 \%$ in the surface horizon [6]. The nitrogen content is high or average [7]. Favorable water, air indicate that these soils have been used for agriculture since ancient times. The soils are characterized by a low store of nutrient elements. Low content of organic colloids and coarse texture characterize the soils as such with low Cation Exchange Capacity (CEC) 10 $15 \mathrm{meq} / 100 \mathrm{~g}$ and low buffer properties [8]. These soils can be used for growing of high yield cultures if fertilized properly [1;9]. Fluvisols are found between Chernozems and Gray forest soils in Northern Bulgaria, along the rivers - Danube, Lom, Ogosta, Iskar, Osam, Yantra, Rositsa and Kamchia $[10 ; 11]$. In Southern Bulgaria they are situated between Vertisols and Cinnamonic Forest soils [12; 1]. A main soil-forming factor is the nature of the alluvial deposit [13], which differs depending on the adjacent water basin that has carried the deposits, on the location along the river, and on the distance from the water. The weather conditions are determined by the climate zone of the respective river valley, or where the hollow is located [1].

\section{MATERIALS AND METHODS}

The object. Fluvisols [14] occurring on the territory of "Kriva Bara" sand and gravel deposit (so far unexploited), located $1.5 \mathrm{~km}$ north-northeast of LevskiG District, Sofia, Bulgaria were the target of the study. Usually this soil type is found in the Lower forest vegetation zone $(0-600 \mathrm{~m}$ a. s. 1 .) of the Moesian forest vegetation area [15].

Methods of study. Sixteen soil pits were done at representative plots. A systematic sampling design was used [16]. The samples were taken at a depth of 0-20 cm, 20-40 cm, 40-60 cm, $60-80 \mathrm{~cm}$ and 80-100 $\mathrm{cm}$. The following methods were used to analyze the soil samples: Bulk density (BD, g.cm $\left.{ }^{-3}\right)$, according to the Kachinsky method [17, 18]; Total porosity (TP, \%) through calculation from bulk density and relative density [17]; Plant available water capacity (PAWC, mm), by a laboratory method, through calculation from field capacity and permanent wilting point [17]; Soil texture (Sand - $2 \mathrm{~mm}-63$ $\mu \mathrm{m}, \%$; Silt $-63 \mu \mathrm{m}-2 \mu \mathrm{m}, \%$; Clay $<2 \mu \mathrm{m}, \%$ ), using the sedimentation method [19]; Soil Organic Matter (SOM, \%) by the Turin method [17]; Total Kjeldahl Nitrogen (TKN, \%) content, by a modified version of the classic Kjeldahl method (Tecator 1030); $\quad \mathrm{P}_{2} \mathrm{O}_{5} \quad\left(\mathrm{mg} .100 \mathrm{~g}^{-1}\right) \quad$ - extraction with Ammonium Acetate and Calcium Lactate-pH 4.2 (UV-VIS spectrophotometer Perkin Elmer Lambda 5) $[20] ; \quad \mathrm{K}_{2} \mathrm{O} \quad\left(\mathrm{mg} \cdot 100 \mathrm{~g}^{-1}\right)$ - extraction with Ammonium Acetate and Calcium Lactate-pH 4.2 (Flame photometer Jenway php 7) [20]; Soil acidity $\left(\mathrm{pH}\right.$ in water extraction and $\mathrm{CaCl}_{2}$ extraction 1:5 $\mathrm{w} / \mathrm{v}$ ) - measured potentiometrically (WTW $720 \mathrm{pH}$ meter); $\mathrm{CaCO}_{3}(\%)$ by Shaibler's method (Eijkelkamp 08.53 calcimeter) [21].

Data analysis. Desciptive statistics was done using Numbers and Excel on Mac and PC, respectively. Percentage data were arcsine-square root transformed 
before the analysis [22]. Pearson's product-moment correlation among the soil characteristics studied was calculated using SPSS for Windows, version 16.0. Linear regression analysis was applied for additional testing for functional relationship between the soil depth and the other characteristics.

\section{RESULTS AND DISCUSSION}

\section{Soil formation process}

The soil forming factors influence the nature, direction and speed of soil forming processes [1]. The key factors are climate, biota, topography, and parent material.

The climate has a direct influence on the temperature and moisture of the soil, and an indirect one on the biota. In terms of climate, the subject of study falls within the European continental climatic region, temperate continental sub-region, climatic region of the high fields of Mid-Western Bulgaria [25]. The average temperatures in January are about $4-5^{\circ} \mathrm{C}$, and the average temperatures in June are $20-21^{\circ} \mathrm{C}$. The average annual temperature of the studied area varies around $11.5^{\circ} \mathrm{C}$, the average annual rainfall varies around $837 \mathrm{~mm}$, with a peak rainfall in May and a minimum in July [25]. Higher plants are the most significant biotic factors that shape the formation of soils, microclimate, supply the soil with organic matter and influence its composition and properties [26]. A number of plant species are closely related to the soil properties by influencing plant development, or by indicating changes in the soil substrate $[27 ; 28 ; 29 ; 30]$. The soils have been formed under poorly developed meadow vegetation $[31 ; 32 ; 26]$. Forests develop less frequently on such soils [31], but if they do, in Bulgaria they form riparian ecosystems dominated by poplars

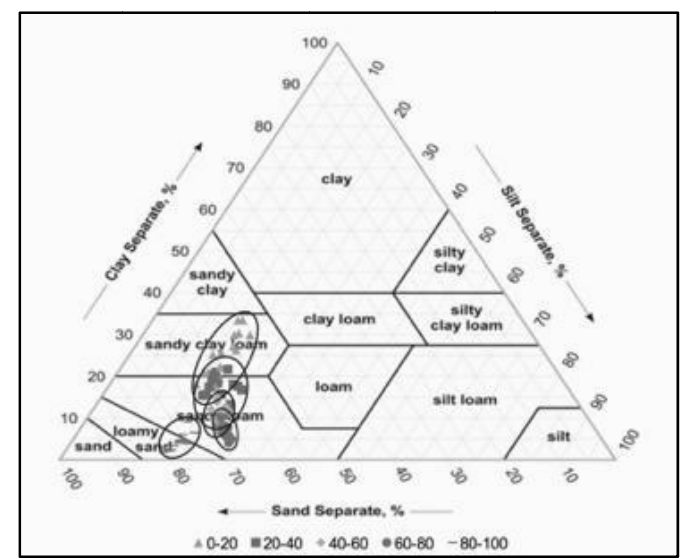

Fig. 1. Soil texture [24]
(Populus spp.) and willows Salix spp., and less frequently - by Common oak (Quercus robur) and Ashes (Fraxinus spp.) [33]. Meadow-marsh vegetation and more rarely, salt tolerant vegetation develop in lower regions [31]. The parent material is a river deposit, mostly sandy, which becomes finer and finer as the river flows from its source to its mouth. It is layered due to its periodic precipitation when rivers burst their banks $[32 ; 1]$. These soils are young, at an early stage of development. Their periodic flushing by fast-flowing rivers during flooding and the precipitation of new sediments prevent the occurrence of permanent vegetation and soil formation $[32 ; 1]$. Over the short period of their existence no genetic horizons have formed $[26 ; 1]$.

Soil characteristics. Soil physical parameters changed slightly with the soil depth. The soil texture at a depth of 0-20 cm fell into the Sandy Loam and mostly in Sandy Clay Loam groups. At a depth of $20-40 \mathrm{~cm}$ it fell into the Sandy Clay Loam and mostly in Sandy Loam texture group. At a depth of $40-60,60-80 \mathrm{~cm}$ it fell into the sandy loam texture group. The samples at a depth of $80-100 \mathrm{~cm}$ fell into Sandy Loam and mainly into the Loam Sand group (Fig. 1). The soil texture variability is consistent with a study carried out by Singh et al [23].

The variation of soil texture with depth was characterized by a negative linear relationship with high statistical significance for the clay fraction $\left(\mathrm{R}^{2}=0.817, \mathrm{p}<0.001\right)$, positive linear relationship with high statistical significance for the sand fraction $\left(\mathrm{R}^{2}=0.7421, \quad \mathrm{p}<0.001\right)$ and positive linear relationship with high statistical significance for the sand fraction $\left(\mathrm{R}^{2}=0.1783, \mathrm{p}<0.001\right)$ (Fig. 2).

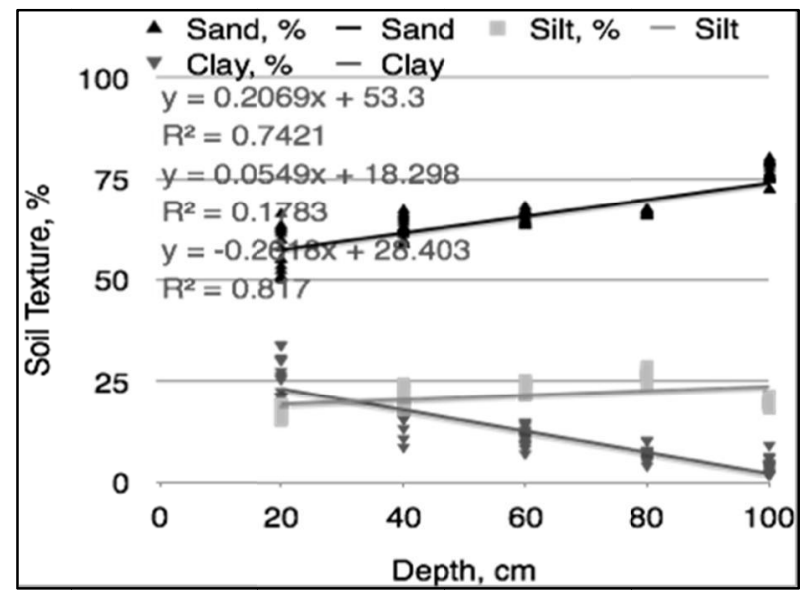

Fig. 2. Relationship between depth and soil texture characteristics 
The bulk density values were between 1.22 and $1.32 \mathrm{~g} . \mathrm{cm}^{-3}$ (Mean $=1.27$, Coeff. of variation $=$ $2.88 \%)$ in the upper $(0-20 \mathrm{~cm})$ layer, varied between 1.29 and $1.43 \mathrm{~g} . \mathrm{cm}^{-3}$ (Mean $=1.33$, Coeff. of variation $=2.84 \%)$ in the $20-40 \mathrm{~cm}$ layer, between 1.35 and $1.46{\mathrm{~g} . \mathrm{cm}^{-3}}^{-3}$ Mean $=1.39$, Coeff. of variation $=2.12 \%)$ in the $40-60 \mathrm{~cm}$ layer, between 1.40 and $1.49 \mathrm{~g} . \mathrm{cm}^{-3}$ (Mean $=1.45$, Coeff. of variation $=2.01 \%$ ) in the $60-80 \mathrm{~cm}$ layer and 1.42 and $1.53{\mathrm{~g} . \mathrm{cm}^{-3}}^{-}$(Mean $=1.48$, Coeff. of variation $=$ $1.56 \%)$ in the lower $(80-100 \mathrm{~cm})$ layer. Despite the weak upward trent of the maximum bulk density values with depth, there was significant relationship between the depth and the bulk density $\left(\mathrm{R}^{2}=0.844\right.$, $\mathrm{p}<0.001$ ) (Fig. 3).

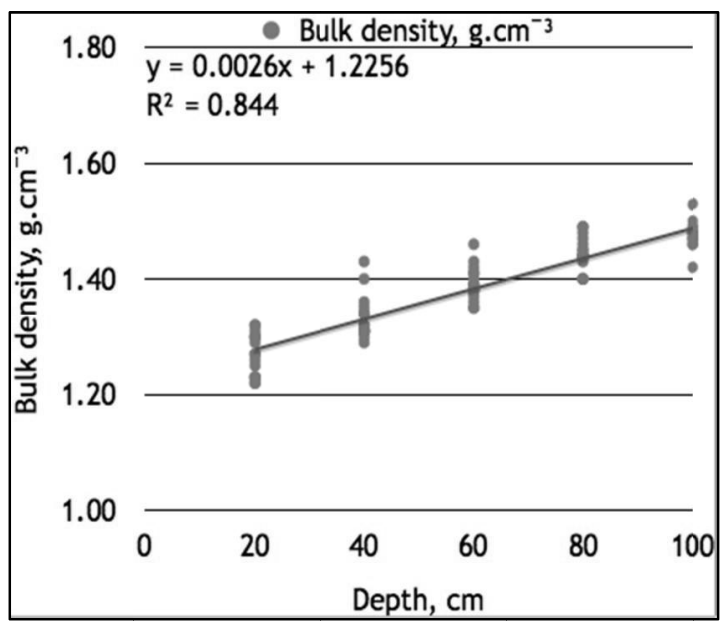

Fig. 3. Relationship between soil depth and porosity

The study of the Fluvisoils showed that there was a clear downward trend in porosity with depth $\left(\mathrm{R}^{2}=0.8716, \mathrm{p}<0.001\right)($ Fig. 4)

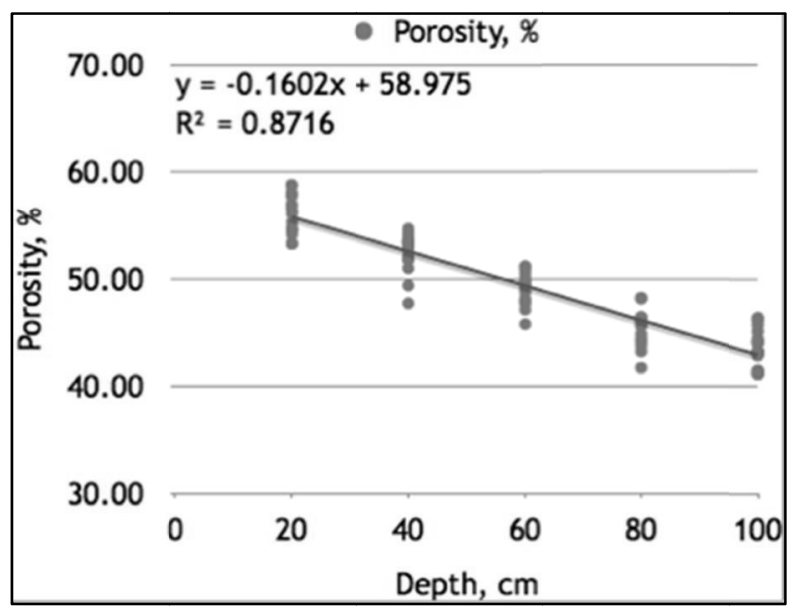

Fig. 4. Relationship between soil depth and porosity
Pearson's product-moment correlation coefficients express the relationships among the soil characteristics (Table 1). It can be seen that roughly three-quarters of the correlation coefficients (49 of 78) are significantly different from zero. In other words, there are significant relationships among different soil characteristics. There is high significant positive correlation between the clay fraction and porosity $(r=0.967)$ and a negative one between the clay fraction and Bulk density $(\mathrm{r}=-$ 961). The clay content correlates significantly with PAWC, SOM, TKN, $\mathrm{P}_{2} \mathrm{O}_{5}$ and $\mathrm{K}_{2} \mathrm{O}$ (positively). Sand content correlates (positively) significantly only with bulk density and $\mathrm{pH}\left(\mathrm{H}_{2} \mathrm{O}\right)$ and all other significant correlations are negative. (Table 1).

PAWC in the studied soils varied from 164.18 $\mathrm{mm}$ to $173.08 \mathrm{~mm}$ (Mean $=168.91$, Coeff. of variation $=1.31 \%$ ) and evaluation of the soils was medium.

The $\mathrm{pH}$ values in the $\mathrm{H}_{2} \mathrm{O}$ extract were between 5.90 and 6.95 (Mean $=6.3 .5$, Coeff. of variation $=$ $6.11 \%)$ in the upper $(0-20 \mathrm{~cm})$ layer, $\mathrm{pH}$ varied between 5.58 and 7.21 (Mean $=6.35$, Coeff. of variation $=10.01 \%)$ in the $20-40 \mathrm{~cm}$ layer, between 5.66 and 6.45 (Mean $=6.01$, Coeff. of variation $=$ $3.32 \%$ ) in the $40-60 \mathrm{~cm}$ layer, between 5.59 and 6.84 (Mean $=6.08$, Coeff. of variation $=6.26 \%)$ in the $60-80 \mathrm{~cm}$ layer and between 5.84 and 7.56 (Mean $=6.68$, Coeff. of variation $=7.34 \%$ ) the lower $(80-100 \mathrm{~cm})$ layer. The $\mathrm{pH}$ values in the $\mathrm{CaCl} 2$ extract were between 5.13 and 6.50 (Mean $=$ 5.78 , Coeff. of variation $=6.66 \%$ ) in the upper $(0-20 \mathrm{~cm})$ layer, $\mathrm{pH}$ varied between 4.92 and 6.71 $($ Mean $=5.85$, Coeff. of variation $=10.54 \%)$ in the 20-40 $\mathrm{cm}$ layer, between 4.98 and 6.06 (Mean = 5.44 , Coeff. of variation $=5.17 \%$ ) in the $40-60 \mathrm{~cm}$ layer, between 5.03 and 6.16 (Mean $=5.53$, Coeff. of variation $=6.04 \%$ ) in the $60-80 \mathrm{~cm}$ layer and between 5.11 and 7.11 (Mean $=6.04$, Coeff. of variation $=8.94 \%)$ in the lower $(80-100 \mathrm{~cm})$ layer. There was weakly expressed linear relationship between the soil reaction in $\mathrm{H}_{2} \mathrm{O}$ and soil depth $\left(\mathrm{R}^{2}=0.0133, \mathrm{p}=0.3086\right)$ and no relationship between the soil reaction in $\mathrm{CaCl}_{2}$ and soil depth $\left(\mathrm{R}^{2}=0.0033, \mathrm{p}=0.612\right)$.

The values of the carbonate content were relatively low, which had been expected based on the $\mathrm{pH}$ data. There was no significant linear relationship between $\mathrm{CaCO}_{3}$ and depth $\left(\mathrm{R}^{2}=0.0263\right.$, $\mathrm{p}=0.150$ ). 
Table 1. Matrix of the correlation coefficients among the soil characteristics studied

\begin{tabular}{|c|c|c|c|c|c|c|c|c|c|c|c|c|}
\hline & 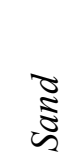 & $\overrightarrow{\tilde{n}}$ & $\frac{\overrightarrow{0}}{\overrightarrow{0}}$ & 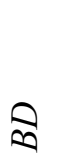 & $\hat{E}$ & $\underset{\Omega}{\stackrel{\Xi}{Z}}$ & 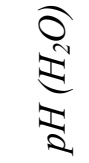 & 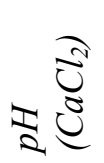 & $\overbrace{0}^{\infty}$ & Ð & $\gtreqless$ & $0^{n}$ \\
\hline Silt & $\frac{\infty}{\dot{0}}$ & & & & & & & & & & & \\
\hline Clay & 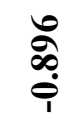 & $\begin{array}{c}\text { No } \\
\text { in } \\
\stackrel{9}{1}\end{array}$ & & & & & & & & & & \\
\hline$B D$ & $\begin{array}{l}\mathscr{0} \\
\infty \\
0 \\
0\end{array}$ & ר⿱乛龰 & 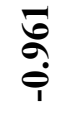 & & & & & & & & & \\
\hline$T P$ & 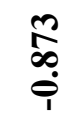 & 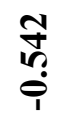 & $\begin{array}{l}\hat{6} \\
\hat{0}\end{array}$ & 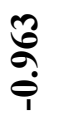 & & & & & & & & \\
\hline$P A W C$ & 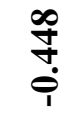 & $\begin{array}{l}\text { ln } \\
\text { nn } \\
0\end{array}$ & $\stackrel{\infty}{\infty}$ & ले & ஜे. & & & & & & & \\
\hline $\begin{array}{c}p H \\
\left(H_{2} \mathrm{O}\right)\end{array}$ & $\underset{\tilde{\sigma}}{\tilde{\theta}}$ & $\stackrel{P}{+}$ & $\stackrel{\nabla}{\circ}$ & $\begin{array}{l}\vec{J} \\
0\end{array}$ & $\begin{array}{l}\overline{8} \\
\stackrel{0}{0}\end{array}$ & $\begin{array}{l}\stackrel{\infty}{0} \\
\text { ஸ̣ } \\
\text { î }\end{array}$ & & & & & & \\
\hline $\begin{array}{c}p H \\
(\mathrm{CaCl})\end{array}$ & $\frac{\infty}{0}$ & 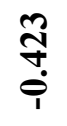 & $\begin{array}{c}m \\
0 \\
0\end{array}$ & 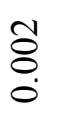 & के & 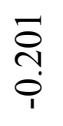 & $\frac{a}{a}$ & & & & & \\
\hline $\mathrm{CaCO}_{3}$ & $\begin{array}{l}2 \\
0 \\
0 \\
0\end{array}$ & $\frac{\vec{m}}{\dot{0}}$ & $\frac{n}{a}$ & $\frac{\stackrel{N}{O}}{\stackrel{0}{i}}$ & $\stackrel{m}{=}$ & 鯜 & $\begin{array}{l}n \\
0 \\
0\end{array}$ & 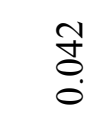 & & & & \\
\hline$S O M$ & $\begin{array}{l}\overline{8} \\
\text { ọ } \\
\text { ì }\end{array}$ & $\frac{+}{\infty}$ & $\begin{array}{l}\bar{\infty} \\
0 \\
0 \\
0\end{array}$ & 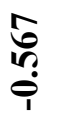 & $\begin{array}{l}n \\
n \\
n \\
0\end{array}$ & $\stackrel{0}{0}$ & $\begin{array}{l}0 \\
0 \\
0 \\
0 \\
1\end{array}$ & $\begin{array}{l}0 \\
\stackrel{0}{0} \\
\stackrel{0}{1}\end{array}$ & 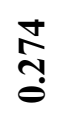 & & & \\
\hline$T K N$ & \begin{tabular}{l}
$\infty$ \\
\multirow{1}{n}{} \\
$\stackrel{0}{1}$
\end{tabular} & ڤั: & $\begin{array}{l}n \\
0 \\
0\end{array}$ & 告 & $\begin{array}{l}n \\
\infty \\
0 \\
0 \\
0\end{array}$ & ஜ̊ & $\begin{array}{l}\infty \\
0 \\
0 \\
1\end{array}$ & $\vec{\sigma}$ & $\frac{\infty}{\pi}$ & 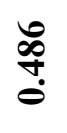 & & \\
\hline $\mathrm{P}_{2} \mathrm{O}_{5}$ & के & 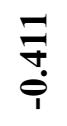 & $\stackrel{a}{+}$ & $\stackrel{n}{\stackrel{n}{+}}$ & ڤ̊. & $\stackrel{\sqrt[n]{0}}{\stackrel{0}{0}}$ & $\stackrel{\tilde{n}}{\tilde{\theta}}$ & ڤั. & $\stackrel{\infty}{\stackrel{\infty}{0}}$ & $\frac{m}{\pi}$ & ले & \\
\hline $\mathrm{K}_{2} \mathrm{O}$ & $\begin{array}{l}\text { qे̣ } \\
\text { ì }\end{array}$ & 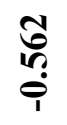 & $\stackrel{8}{9}$ & $\frac{\substack{+\dot{1}}}{i}$ & $\underset{\dot{\sigma}}{\stackrel{7}{\theta}}$ & Oे & $\begin{array}{l}\overline{8} \\
\dot{0} \\
\end{array}$ & $\stackrel{n}{8}$ & 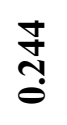 & 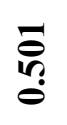 & $\overline{7}$ & חֶ̆ \\
\hline
\end{tabular}

Legend: The values in Bold indicate a statistically significant correlation at $\mathrm{p} \leq 0.05$.

For abbreviations of the names of soil characteristics, see part "Material and Methods" 
The studied soils were generally characterized by low SOM and TKN values, which is consistent with Donov [1] and Singh et al. [23]. The SOM and TKN were between 0.91 and $2.30 \%$ (Mean $=1.66$, Coeff. of variation $=27.97 \%), 0.015$ and $0.023 \%$ (Mean $=0.020$, Coeff. of variation $=11.03 \%)$ in the upper $(0-20 \mathrm{~cm})$ layer, between 0.35 and $1.96 \%$ (Mean $=1.14$, Coeff. of variation $=48.73 \%), 0.008$ and $0.017 \%$ (Mean $=0.012$, Coeff. of variation $=26.41 \%$ ) at $20-40 \mathrm{~cm}, 0.69-1.71 \%$ (Mean $=1.19$, Coeff. of variation $=30.66 \%)$ and 0.008 $0.017 \%$ (Mean $=0.013$, Coeff. of variation $=23.39 \%)$ at

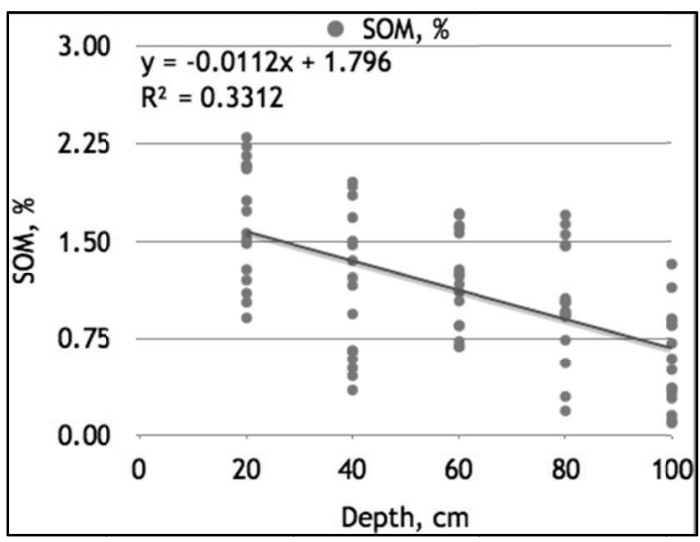

Fig. 5. Relationship between depth and SOM

The $\mathrm{P}_{2} \mathrm{O}_{5}$ and $\mathrm{K}_{2} \mathrm{O}$ were between 0.09 and 0.40 $\mathrm{mg} .100 \mathrm{~g}^{-1}($ Mean $=0.23$, Coeff. of variation $=50.57 \%)$, 31.08 and $56.78 \mathrm{mg} \cdot 100 \mathrm{~g}^{-1}$ (Mean $=42.28$, Coeff. of variation $=17.73 \%)$ in the upper $(0-20 \mathrm{~cm})$ layer, between 0.05 and $0.22 \mathrm{mg} \cdot 100 \mathrm{~g}^{-1}$ (Mean $=0.15$, Coeff. of variation $=40.53 \%), 10.13$ and $16.12 \mathrm{mg} .100 \mathrm{~g}^{-1}$ $($ Mean $=12.85$, Coeff. of variation $=15.54 \%)$ at $20-40$ $\mathrm{cm}, 0.01-0.18 \mathrm{mg} .100 \mathrm{~g}^{-1}$ (Mean $=0.02$, Coeff. of variation $=174.34 \%)$ and $9.03-15.22 \mathrm{mg} .100 \mathrm{~g}^{-1}$ (Mean $=11.76$, Coeff. of variation $=17.81 \%$ ) at $40-60 \mathrm{~cm}$ depth, between 0.10 and $0.14 \mathrm{mg} .100 \mathrm{~g}^{-1}$ (Mean $=0.12$,

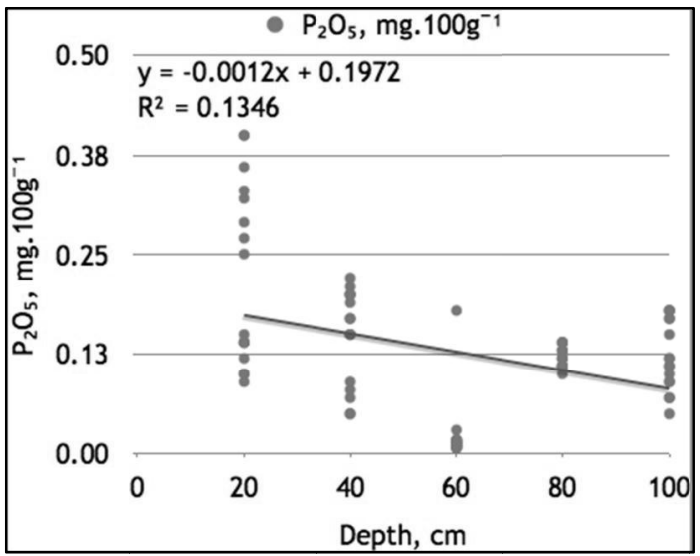

Fig. 7. Relationship between soil depth and $\mathrm{P}_{2} \mathrm{O}_{5}$ content
40-60 $\mathrm{cm}$ depth, between 0.19 and $1.70 \%$ (Mean $=1.03$, Coeff. of variation $=43.68 \%$ ), 0.008 and $0.018 \%$ (Mean $=0.012$, Coeff. of variation $=28.40 \%$ ), at $60-80 \mathrm{~cm}$ and between 0.10 and $1.32 \%$ (Mean $=0.59$, Coeff. of variation $=62.82 \%), 0.006$ and $0.014 \%$ (Mean $=0.010$, Coeff. of variation $=28.37 \%$ ) respectively in the lower $(80-100 \mathrm{~cm})$ layer. There was a strong linear negative relationship between $\mathrm{SOM}$ and the depth $\left(\mathrm{R}^{2}=0.3312\right.$, $\mathrm{p}<0.001$ ), and a strong linear negative relationship between TKN and the depth $\left(\mathrm{R}^{2}=0.4003, \mathrm{p}<0.001\right)$ (Figures 5 and 6).

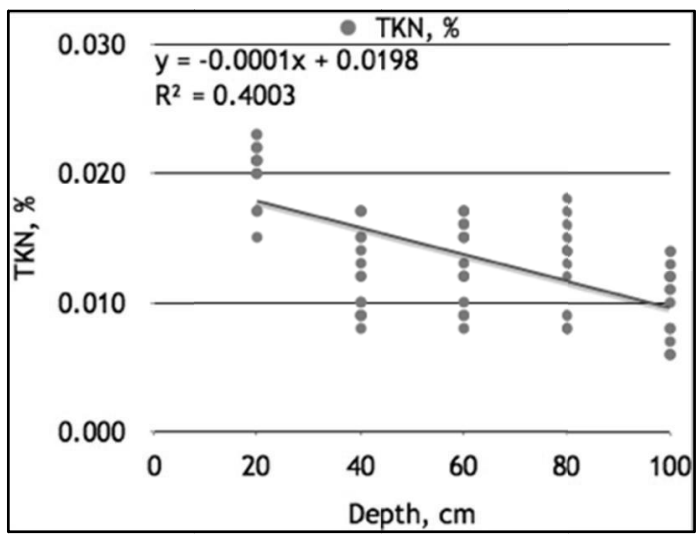

Fig. 6. Relationship between depth and TKN

Coeff. of variation $=10.69 \%$ ), 8.15 and $12.43 \mathrm{mg} \cdot 100 \mathrm{~g}^{-1}$ $($ Mean $=9.99$, Coeff. of variation $=14.10 \%)$, at $60-80$ $\mathrm{cm}$ and between 0.05 and $0.12 \mathrm{mg} \cdot 100 \mathrm{~g}^{-1}$ (Mean $=0.12$, Coeff. of variation $=35.83 \%$ ), 6.49 and $10.84 \mathrm{mg} .100 \mathrm{~g}^{-1}$ $($ Mean $=8.01$, Coeff. of variation $=16.39 \%$ ) respectively in the lower $(80-1000 \mathrm{~cm})$ layer. There were low linear negative relationships between $\mathrm{P}_{2} \mathrm{O}_{5}$ and depth $\left(\mathrm{R}^{2}=0.1346, \mathrm{p}<0.001\right.$, fig. 7$)$, and medium linear negative relationships between $\mathrm{K}_{2} \mathrm{O}$ and depth $\left(\mathrm{R}^{2}=0.5808, \mathrm{p}<0.001\right.$, Fig. 8$)$.

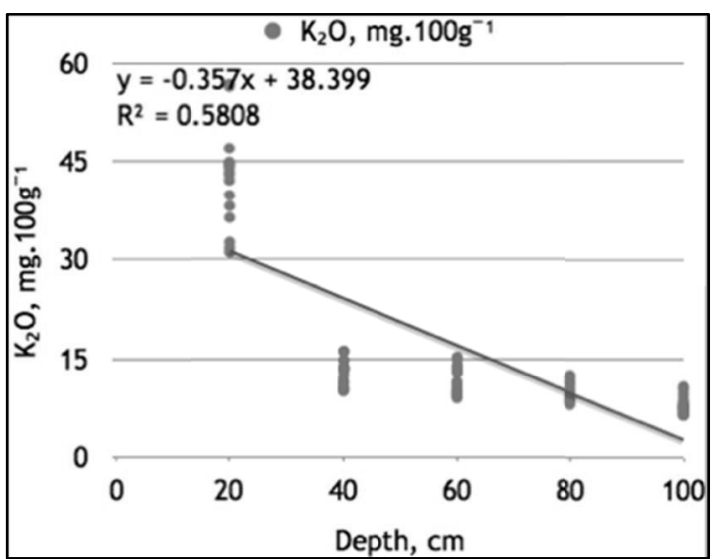

Fig. 8. Relationship between soil depth and $\mathrm{K}_{2} \mathrm{O}$ content 
Plant cover. Total 19 species were recorded in the scoring plots (Table 2). It should be pointed out that these plants represent late summer and partly the autumn spectrum, because the study was performed in August-September. The plants from the early vegetation period remained undetected. There was one shrub species (Rubus caesius), thirteen perennial plant species, three annuals and two biennials.
The phytogeographic analysis revealed that there are 8 Euro-Asiatic floristic elements, followed by 3 Euro-Siberian. Boreal and Euro-Mediterranean elements are represented by 2 species each, and there are also one SubBoreal, one PonticMediterranean element, one subMediterranean and one European element.

Table 2. Plant species recorded in the scoring plots

\begin{tabular}{|c|lll|}
\hline No & Species & Phytogeographic origin & Biological type \\
\hline 1 & Achillea millefolium L. & Eur-Sib & perennial \\
\hline 2 & Agrimonia eupatoria L. & Eur-Med & perennial \\
\hline 3 & Alopecurus pratensis L. & Eur-As & perennial \\
\hline 4 & Arrhenatherum elatius (L.) P. Beauv. ex J.\&C. Presl & Eur-As & perennial \\
\hline 5 & Artemisia vulgaris L. & subBoreal & perennial \\
\hline 6 & Centaurea solstitialis L. & eur-Med & annual \\
\hline 7 & Conium maculatum L. & Eur-As & annual \\
\hline 8 & Crepis biennis L. & subMed & biennial \\
\hline 9 & Dactylis glomerata L. & Eur-As & perennial \\
\hline 10 & Echium vulgare L. & Eur-As & biennial \\
\hline 11 & Elymus repens (L.) Gould. & Boreal & perennial \\
\hline 12 & Eryngium campestre L. & Pond-Med & perennial \\
\hline 13 & Galium verum L. & Eur-As & perennial \\
\hline 14 & Holcus lanatus L. & Eur & perennial \\
\hline 15 & Hordeum murinum L. & Boreal & annual \\
\hline 16 & Tanacetum vulgare L. & Eur-Sib. & perennial \\
\hline 17 & Linaria vulgaris Mill. & Eur-Sib & perennial \\
\hline 18 & Lolium perenne L. & Eur-As & perennial \\
\hline 19 & Rubus caesius L. & Eur-As & shrub \\
\hline
\end{tabular}

\section{CONCLUSIONS AND RECOMMENDATIONS}

The specific soil formation factors for soils of Fluvisols group determined a variation of different soil characteristics (such as $\mathrm{CaCO}_{3}, \mathrm{pH}\left(\mathrm{H}_{2} \mathrm{O}\right)$, etc) and because of this there were weak relationships between different soil characteristics and soil depth. There were moderate to high relationships between some physical soil characteristic such as Soil texture, Bulk density, Porosity, and some chemical soil characteristic such as Total Kjeldahl Nitrogen, $\mathrm{K}_{2} \mathrm{O}$ and soil depth and weak and insignificant relationships between the other characteristics and soil depth.

The studied soils were characterized by some favorable physical properties, e.g. light by texture, porosity and unfavorable physical properties like bulk density which varied from compacted to very dense. PAWC evaluation was medium. The high content of inert texture fraction (Sand) determined the low content of SOM and nutrient elements $\left(\mathrm{TKN}\right.$ and $\left.\mathrm{P}_{2} \mathrm{O}_{5}\right)$ especially in lower layers, apart from $\mathrm{K}_{2} \mathrm{O}$. The $\mathrm{K}_{2} \mathrm{O}$ content was high. The $\mathrm{CaCO}_{3}$ content was low which determined $\mathrm{pH}\left(\mathrm{H}_{2} \mathrm{O}\right)$ between slightly acidic to neutral.

The studied object is situated close to district Levski-G of Sofia city agglomeration. The decrease of green areas in Sofia, on the one hand, and the unfavorable effect of the mining activities on the territory of Krivina, on the other, underline the necessity of establishment of a park territory in the zone of the still nonexploited locality. Considering the soil characteristics in the object, we could recommend for cultivation some arboreal species: indigenous Pinus nigra Arnold, Quercus robur L., Quercus cerris L., Fraxinus oxycarpa Willd., Celtis australis L., Ulmus minor Mill., Syringa vulgaris L., Cotinus coggygria Scop.; exotic - Cedrus atlantica Manetti, Cupressus sempervirens L., Quercus rubra L., Ulmus pumila L., Morus alba L., and many ornamental shrubs with more or less pronounced drought resistance. 


\section{REFERENCES}

[1] Donov, V., Forest soil science. Martilen Publishing House, 1993, p. 430 (in Bulgarian)

[2] Dengiz, O., Morphology, physico-chemical properties and classification of soils on terraces of the Tigris River in the south-east Anatolia region of Turkey. Tarim Bilimleri Dergisi, 16(3), 2010, 205-212

[3] Woźniak, L., Kud, K., Organic matter and some element contents in soil profiles of alluvial water race in the mountain regions of bieszczady-Poland. Soil organic matter and element interactions. In $\mathrm{K}$. Aichberger (Ed.), soil organic matter andelement interactions, 2005, pp. 110-120

[4] Duchaufour, P., Precis de Pedologie, Soil Science, 1965 , p. 587

[5] Kaczmarek, Z., Gajewski, P., Mocek, A., Geobotanical conditions of ecological grasslands on fine textured fluvisols, Journal of Research and Applications in Agricultural Engineering, Vol. 60(3), 2015, 131-135

[6] Mitkova, T., Mitrikeski, J., Soils of the Republic of Macedonia: present situation and future prospects, Jones, RJ A., Houskova, B., Bullock, P. \& Montanarella, L.(eds.), Soil resources of Europe, 2005, 225-234

[7] Yigini, Y., Panagos, P., Montanarella, L. Soil resources of mediterranean and Caucasus countries. Office for Official Publications of the Euroean Communities, Luxembourg. 2013. p. 237

[8] Shishkov, T., Kolev, N. The soils of Bulgaria. Springer, Dordrecht, The Netherlands. 2014. p. 224

[9] Kalala, A. M., B. M. Msanya, N. A. Amuri, J. M. Semoka. Pedological characterization of some typical alluvial soils of Kilombero District, Tanzania. American Journal of Agriculture and Forestry 2017; 5(1): $1-11$

[10] Teoharov, M., T. Shishkov, B. Hristov, E. Filcheva, R. Ilieva, I. Lyubenova, I. Kirilov, G. Dimitrov, V. Krasteva, B. Georgiev, M. Banov, P. Ivanov, M. Hristova, Z. Mitreva. Chernozems in Bulgaria - systematics, specific features and problems. Chernozems in Bulgaria. Problems, assessment, use and protection. Scientific papers, 2015. pp. 20-34. (in Bulgarian)

[11] Hristov, B. Pedometric and taxonomic characteristics of primitive soils formed on the soft rocks in the Chernozem area in Northern Bulgaria. Dissertation. Archive of Soil Science Institute "N. Pushkarov", Sofia, 2009. p. 147. (in Bulgarian)

[12] Antipov-Karataev, I. N., V.V. Galeva, I. P. Gerasimov, K. X. Enikov, E. N. Tanov, I. V. Tiurin. Soils in Bulgaria. Academy of Science USSR. 1959. p. 398 (In Russian)
[13] Aubert G., Boulaine J. La Pédologie. Paris, Presses Universitaires de France, Que Sais-Je ? N ${ }^{\circ}$ 352. 1972. p. 126

[14] IUSS Working Group WRB. 2014. World reference base for soil resources 2014. International soil classification system for naming soils and creating legends for soil maps. World Soil Resources Reports No. 106. FAO, Rome, Italy

[15] Zahariev, B., Donov V., Petrunov K., Massurov S. Forest vegetation zoning of the People's Republic of Bulgaria. Zemizdat. 1979. p. 195. (In Bulgarian)

[16] Petersen, R.G., Calvin, L.D. Sampling. p. 118. In J. M. Birgham (Ed.) Methods of soil analysis, Part 3. Chemical methods, No. 5. Madison, WI: Soil Science Society of America. 1996.

[17] Donov, V., S. Gencheva, K. Yorova. A manual for practical seminars in Forest soil science, Zemizdat, 1974, p. 216 (in Bulgarian)

[18] DIN ISO 11272:1998, 2001, Soil quality Determination of dry bulk density

[19] ISO 11277: Soil quality - Determination of particle size distri- bution in mineral soil material Method by sieving and sedimen- tation (ISO 11277:1998+ ISO 11277:1998 Corrigendum 1:2002)

[20] Ivanov, P. New AL method to determined the plants available phosphorus and potassium in soil. Soil and agrochemistry. 4., 1984. 88-98. (In Bulgarian)

[21] NEN-ISO 10693, Soil quality. Determination of carbonate content. Volumetric method, 2004, [http://www.nen.nl]

[22] Compton, M.E. Statistical methods suitable for analysis of plant tissue culture data. Plant Cell, Tissue and Organ Culture, 37(3): 1994, 217-242

[23] Singh, R. N., Singh, R. N. P., Diwakar, D. P. S. Characterization of old alluvial soils of Sone basin. Journal of the Indian Society of Soil Science, 48(2), 2000, 352-357 pp.

[24] Soil Survey Staff. Soil taxonomy, a basic system of soil classification for making and interpreting soil surveys, United States Department of Agriculture, Handbook № 436, 1975

[25] Troeva V., Environmental assessment of a change in the General Master Plan of Sofia and Sofia municipality, Vol. 1: 2009. 70-300, http://www.sofproect.com/ovos_web.aspx. Last visited 05.01.2014 (in Bulgarian)

[26] Donov, V. Forest soil science, Zemizdat, 1979, p. 411 (in Bulgarian)

[27] Bogdanov, S., P. Glogov. Distribution of ecological groups of plants depending on changes in the composition and properties of soils affected by 
forest fires. Forest Science, vol. 3, 2006. 81-95. (In Bulgarian)

[28] Bogdanov, S., Changes in the acidity of Luvisols under the influence of forest fires, Ecological Engineering and Environmental Protection, № 2/2013, 2013, 61-67 pp. (In Bulgarian)

[29] Bogdanov, S., Plant available water capacity as a factor for the sustainable development of forests affected by forest fires. Management and Sustainable Development. 3/2014 (46), 2014, 23-26 (In Bulgarian)

[30] Bogdanov, S., Savev, S., Tsavkov, E., Investigation on humus-carbonate soils in the Western
Balcan Mountains foothill, Environmental Engineering and Environmental Protection, № 3, 2015, 29-35 (In Bulgarian)

[31] Stransky, I., Soil science, Royal Court Printing Press, 1935, p. 536 (In Bulgarian)

[32] Georgiev, A. G., Soil science, Zemizdat,1959, p. 305 (In Bulgarian)

[33] Bondev, I., The vegetation of Bulgaria. A Map in 1: 600000 scale with explanatory text, Sofia University "St. Kliment Ohridsky" Publ. House, 1991, p. 183

\title{
ХАРАКТЕРИСТИКА НА ПОЧВИ ОТ КЛАС FLUVISOLS В НАХОДИЩЕ НА ЧАКЪЛ И ПЯСЫЦИ "КРИВА БАРА", СОФИЯ, БЪЛГАРИЯ
}

\author{
Владимир Илинкин, Димитьр Димитров, Петьр Желев
}

Резюме: В статията са представени резултатите от проучване на почви от клас Fluvisols, разположени в кариера "Крива Бара" София, България. Почвените проби са взети от шестнадесет почвени профила. Изследвани са физични и химични свойства на почвата. Анализирани са промените по дълбочина на почвените профили, като връзките между различните почвени характеристики са определени чрез корелационен анализ. Резултатите показват, че някои почвени характеристики, като механичен състав, порьозност и TKN, се променят значително по дълбочината на почвения профил с положителна или отрицателна зависимост. Измененията при други почвени характеристики, като $\mathrm{pH}$ и $\mathrm{CaCO}_{3}$, са умерено изразени или са без статистическа достоверност. Съществуват статистически значими зависимости между физичните и химичните свойства на почвата в 49 от 78 случая.

Ключови думи: Fluvisols, физични свойства, химични свойства, находище на чакъл и пясъци, кариера

\section{Vladimir Metodiev Ilinkin*, PhD student}

Institute of Biodiversity and Ecosystem Research - Bulgarian Academy of Sciences

23, Acad. Georgy Bonchev Str.

Sofia, 1113, Bulgaria

e-mail: ilinkin@mail.bg

\section{Dimitar Naskov Dimitrov}

Forest Research Institute - Bulgarian Academy of Sciences Kliment Ohridski Blvd.

Sofia 1756, Bulgaria e-mail: mitkomit@mail.bg

\section{Peter Zhelev}

Forestry University, Sofia, Bulgaria

Bul. "Kliment Ohridsky" 10

Sofia 1756, Bulgaria

e-mail: zhelev@ltu.bg

\section{Владимир Методиев Илинкин}

Институт по биоразнообразие и екосистемни изследвания - БАН ул. “Акад. Г. Бончев" 23

София 1113

e-mail: ilinkin@mail.bg

\section{Димитьр Насков Димитров}

Институт за гората - БАН

бул. Климент Охридски 132

София 1756

e-mail: mitkomit@mail.bg

\section{Петьр Желев}

Лесотехнически университет

бул. “Климент Охридски” 10

София 1756

e-mail: zhelev@1tu.bg

* Corresponding author: Vladimir Ilinkin 